Exp. Anim. 52(4), 329-334, 2003

\title{
Reproductive Features of the Russian Vole in Laboratory Breeding
}

\author{
Diah Tri WIDAYATI 1, 2), Kazuyuki MEKADA3), Sen-ichi ODA3), \\ Elena ZHOLNEROVSKAYA4), Suren Minasovich ZAKIYAN5), \\ and Katsuhiro FUKUTA ${ }^{11}$
}

\begin{abstract}
1)Laboratory of Animal Morphology and Function, Graduate School of Bioagricultural Sciences, Nagoya University, Nagoya 464-8601, Japan, ${ }^{2}$ Faculty of Animal Science, Gadjah Mada University, Yogyakarta 55281, Indonesia, ${ }^{3)}$ Laboratory of Animal Management and Resources, Graduate School of Bioagricultural Sciences, Nagoya University, Nagoya 464-8601, Japan, ${ }^{4)}$ Institute of Systematics and Ecology of Animals, Russian Academy of Sciences, and ${ }^{5}$ Institute of Cytology and Genetics, Russian Academy of Sciences, Russia
\end{abstract}

\begin{abstract}
Reproductive features of newly bred Russian voles (Microtus rossiaemeridionalis) as a laboratory animal were studied. This species is a copulatory ovulator, and most couples copulated 6 to $16 \mathrm{~h}$ after pairing. The gestation period varied from 18 to 22 days (mean $\pm S D: 20.6 \pm 0.9, n=72)$, and the average litter size was $4.6 \pm 1.9(n=125)$. Compared with the litter size at the first parturition (3.6 $\pm 1.6, n=72)$, the litter size in the subsequent parturitions increased to $5.9 \pm 1.4(n=53)$. The animals exhibited postpartum estrus, and repeated pregnancy accompanied with suckling pups and parturition continuously in the laboratory condition unlike other vole species. In view of their complex stomach and good proliferation, the Russian voles were evaluated as a good laboratory animal, especially as a model animal for ruminant studies.
\end{abstract}

Key words: continuous pregnancy, Microtus rossiaemeridionalis, reproductive features

More than 60 species of voles, Microtus spp, inhabit the Northern Hemisphere, and most of them are serious pests of agricultural crops and zoonotic parasite carriers. From these standpoints their population structure has been subjected to detailed research in North America and Northern Europe [14, 24]. Among rodents, field voles are unique in having strong herbivorous features as characterized by a complex stomach and possession of cellulolytic bacteria [16]. Therefore, they are expected to be candidates for laboratory animal models of large domestic ruminants in the fields of animal science and veterinary medicine. Breeding in the laboratory has been successfully performed for several field voles, such as the common vole (M. arvalis) [16], Japanese field vole (M. montebelli) $[6,7]$, prairie vole (M. ochrogaster) [25], tundra vole (M. oeconomus) [5], meadow vole (M. pennsylvanicus) [4], and montane vole (M. pinetorum) [17]. In this paper we examine the reproductive features of the Russian vole, $M$. rossiaemeridionalis which has been newly bred and

(Received 9 October 2002 / Accepted 25 February 2003)

Address corresponding: K. Fukuta, Laboratory of Animal Morphology and Function, Graduate School of Bioagricultural Sciences, Nagoya University, Chikusa 464-8601, Nagoya, Japan 
maintained in the laboratory.

The Russian voles ( $M$. rossiaemeridionalis) used in this experiment originated from wild individuals captured in the Leningradskaya region, Russia, in 1995. They were bred and maintained in a laboratory in Novosibirsk, then introduced to Japan in 2000. All the animals examined were kept as pairs in 22.5 (1) $\times 33.8$ (w) $\times 14.0(\mathrm{~h}) \mathrm{cm}$ polycarbonate transparent cages (CL0104, CLEA, Tokyo) with wood shavings as bedding and nesting materials. They were fed commercial mouse pellets (CA-1, CLEA, Tokyo) and cubed hay. Food and water were provided ad libitum. The animal house was controlled with lighting conditions of $12 \mathrm{~L}$ (6:00-18:00) and $12 \mathrm{D}$ (18:00-6:00) and a temperature of $25 \pm 3^{\circ} \mathrm{C}$. Eight- to 10 -week-old males and females were used as breeding couples. After pairing, the couples were watched every $2 \mathrm{~h}$ for $24 \mathrm{~h}$ and every $4 \mathrm{~h}$ following $12 \mathrm{~h}$, and copulation was confirmed by mounting of males. The females giving no birth within 60 days were culled as 'non-reproducing females' [30]. Gestation period was determined as the period from copulation to parturition, and the litter size was counted at parturition. The young were separated from the parents at about 20 days of age, before the next birth, so that there was no more than one litter of pups in each cage at any time. Parturition interval was counted as days between two successive parturitions. Postpartum mating was not examined, although mounting of males was recognized in some couples. Weaning was judged by feeding behavior and less maternal contact with pups. Infant mortality was calculated as the ratio of the number of dead young until weaning to the number of young born. Body weight was measured at parturition (0 day), 20 days and 6 weeks of age. Sexual maturity of females was estimated as the day of vaginal opening.

Most breeding couples of Russian voles copulated on the first day, in spite of fighting at the time of pairing. As a vaginal plug was not formed, the copulation was confirmed by watching the mounting behavior. The first copulation occurred at 6 to $16 \mathrm{~h}$ after pairing (mean $\pm \mathrm{SD}: 11.8 \pm 3.0, \mathrm{n}=11$ ) and subsequent copulations were repeatedly observed over a period of $24 \mathrm{~h}$. Couples which did not copulate within $16 \mathrm{~h}$ did not copulate thereafter. The gestation period ranged from 18 to 22 days (mean \pm SD: $20.6 \pm 0.9, n=72$ ) and there was no difference between the first and the subsequent pregnancies. It was thought that the variation in the gestation period might be due to the difference in ovulation time after coitus in individual females. In mice the length of the gestation period is influenced by litter size, i.e., the gestation period is elongated in pregnancies with small litter sizes, vice versa. However, the length of the gestation period of Russian vole seemed irrespective of the litter size, because a long gestation period was noted in pregnancies with large litter size, more than 4 , and short periods in small litter sizes. In the continuous pairing, the female became pregnant while nursing, indicating postpartum estrus and coitus. They gave birth continuously, and the parturition interval ranged from 19 to 27 days (mean \pm SD: $22.0 \pm 1.7$, $\mathrm{n}=48$ ).

A total of 575 young were born in 125 parturitions. Litter sizes varied from 1 to 10 (mean \pm SD: $4.6 \pm 1.9$, $\mathrm{n}=125$ ), and a litter size of 4-6 was most frequently observed (Fig. 1). At the first parturition only one or two pups were born frequently so the litter size was smaller at the first parturition $(3.6 \pm 1.6, \mathrm{n}=72)$ than in the subsequent parturitions $(5.9 \pm 1.4, \mathrm{n}=53)$ as shown in Fig. 2. The litter size reached its maximum at the seventh parturition and decreased thereafter. The pups were weaned at 12 to 25 days of age $(16.7 \pm 2.9, n=110)$. The infant mortality before weaning was $14.4 \%$. The young died mostly within the first 5 days after birth. Sometimes, a body part was left as traces of cannibalism, as often seen in other laboratory rodents. It is unknown whether cannibalism happened before or after the death of pups. After 5 days of age, only a few young died until weaning. Table 1 shows body weight at birth from the first to fifth parturitions. Average body weight at birth was $2.3 \pm 0.3 \mathrm{~g}(\mathrm{n}=116)$, ranging from 1.4 to $3.2 \mathrm{~g}$. The first parturition usually produced small pups, and the birth weight increased in the subsequent parturitions. In addition, a decrease in individual variation was observed after the third parturition (Table 1). The average body weight at 20 days of age was $18.7 \pm 3.6 \mathrm{~g}$ (range: $10.9-25.6, \mathrm{n}=96$ ). Body weight at 6 weeks of age was $30.3 \pm 2.7 \mathrm{~g}$ (range: $25.4-35.6$, $\mathrm{n}=49$ ) in males and $25.0 \pm 1.6 \mathrm{~g}$ (range: $20.2-29.2$, $\mathrm{n}=46$ ) in females. Sexual maturity of females was judged by vaginal opening, which was observed between 45-60 days of age (mean \pm SD: $54.0 \pm 3.5$, $\mathrm{n}=28$ ).

Among more than 60 species in genus Microtus, successful breeding in the laboratory has been reported in 


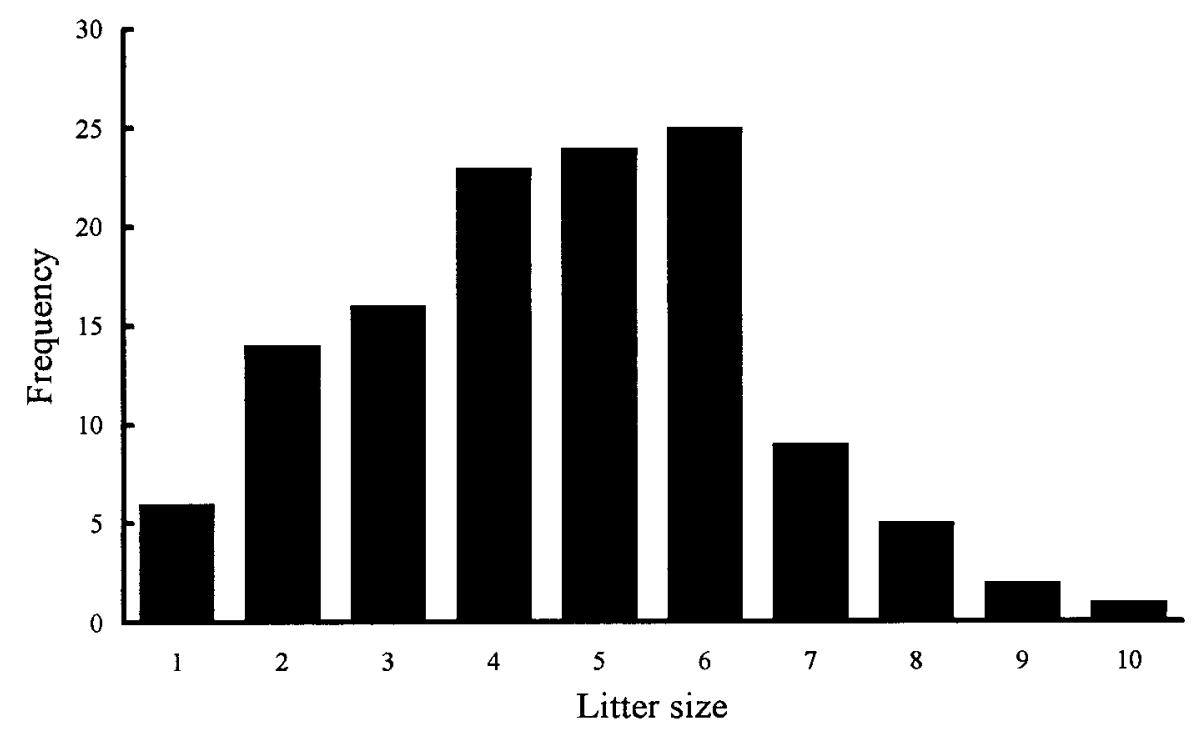

Fig. 1. Frequency distribution of litter size in total parturition.

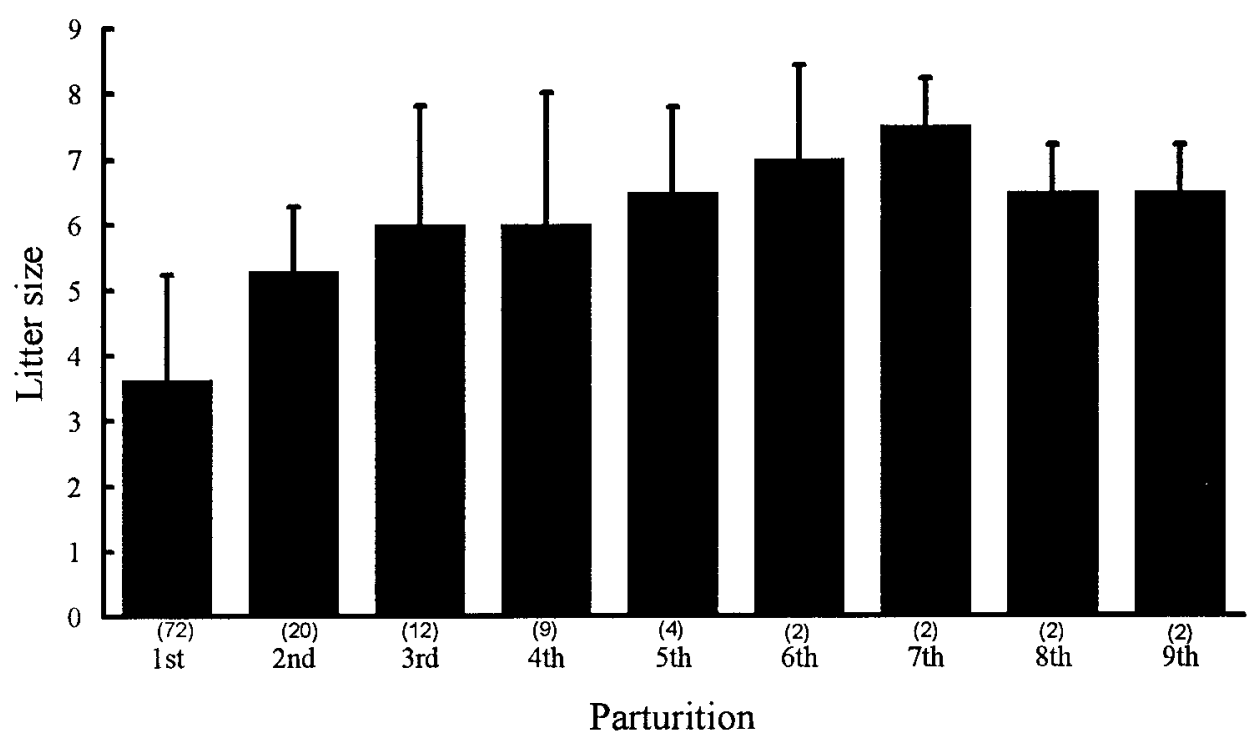

Fig. 2. Litter size from the first to ninth parturitions. Columns and vertical lines indicate mean and standard deviation, respectively. Number in parenthesis shows number of litters examined.

several species such as the common vole [16], Japanese field vole [6,7], prairie vole [25], tundra vole [5], meadow vole [4], and montane vole [17]. In spite of their vigorous proliferation in the natural habitats, captive voles and their descendants are less reproductive in laboratory conditions. The breeding colony of Russian voles (M. rossiaemeridionalis) examined in this study, however, exhibited excellent reproductive per- formance comparable to the commonly used laboratory rodents. The present study confirmed that the Russian vole is a copulatory ovulator and that a vaginal plug is not formed at copulation. Most of the couples copulated on the first day of pairing and repeated coitus over $24 \mathrm{~h}$. The copulation in microtine rodents is generally confirmed by the presence of sperm in a vaginal smear. In this study, the copulation was confirmed by 
Table 1. Body weight at birth in the first to fifth parturitions

\begin{tabular}{cccccc}
\hline Parturition & 1st & 2nd & 3rd & 4th & 5 th \\
\hline Mean \pm SD (g) & $2.24 \pm 0.28(50)$ & $2.35 \pm 0.31(43)$ & $2.50 \pm 0.20(10)$ & $2.56 \pm 0.22(7)$ & $2.73 \pm 0.12(6)$ \\
\hline
\end{tabular}

Number in the parenthesis indicates number of young examined.

Table 2. Some reproductive characteristics in Microtus (Explanation for each item is given in the text)

\begin{tabular}{|c|c|c|c|c|}
\hline Species & $\begin{array}{c}\text { Gestation } \\
\text { Periods (days) } \\
\text { Mean } \pm \text { SD } \\
\text { (range) }\end{array}$ & $\begin{array}{c}\text { Litter } \\
\text { Size } \\
\text { Mean } \pm \text { SD } \\
\text { (range) }\end{array}$ & $\begin{array}{l}\text { Parturition } \\
\text { Interval } \\
\text { (days) } \\
\text { Mean } \pm \text { SD } \\
\text { (range) }\end{array}$ & Reference \\
\hline M. rossiaemeridionalis & $\begin{array}{c}20.6 \pm 0.9(\mathrm{n}=72) \\
(18-22) \\
(20-21)\end{array}$ & $\begin{array}{c}4.6 \pm 1.9(\mathrm{n}=125) \\
(1-10) \\
(2.08-2.28)^{*}\end{array}$ & $\begin{array}{c}22.0 \pm 1.7(\mathrm{n}=48) \\
(19-27) \\
-\end{array}$ & $\begin{array}{c}\text { Present study } \\
35^{* *}\end{array}$ \\
\hline M. arvalis & $\begin{array}{c}20 \\
(16-22)\end{array}$ & $4.75 \pm 1.40$ & $(20-21)$ & 15,16 \\
\hline M. breweri & - & 3.3 & - & 32 \\
\hline M. montanus & 21 & $(4.7-6.0)$ & - & 9,20 \\
\hline M. montebelli & $\begin{array}{c}21 \\
(18-22)\end{array}$ & $\begin{array}{c}3.9 \pm 1.3(\mathrm{n}=27) \\
(1-6)\end{array}$ & - & 16,36 \\
\hline M. ochrogaster & $(21-23)$ & $(3.0-4.6)$ & $24.3 \pm 0.9(n=3)$ & $12,25,31,33$ \\
\hline M. oеconomus & 21 & 3.9 & - & 5,19 \\
\hline M. pennsylvanicus & 21 & $(3.7-6.3)$ & - & 12,19 \\
\hline M. pinetorum & 24 & $(2.2-2.3)$ & $24-72$ & $13,17,29$ \\
\hline M. savii & - & $\begin{array}{c}2.6 \\
(1-4)\end{array}$ & 29.4 & 3 \\
\hline
\end{tabular}

*: Litter size at the first and second parturition. **: Described in the old nomenclature as M. epiroticus.

watching copulatory behavior, i.e., mounting by a male.

Puberty in the female was judged by vaginal opening and estimated to be attained between 45-60 days of age. This is earlier than 77 days in M. pinetorum [29], but later than M. pennsylvanicus [28] ranging 25-38 days. Table 2 summarizes the principal reproductive characteristics of some microtine species. The gestation period of the Russian vole ranged from 18 to 22 days (mean \pm SD: $20.6 \pm 0.9, \mathrm{n}=72$ ), comparable to the previous finding (20-21 days) in M. epiroticus [35], which is considered to be the same species as $M$. rossiaemeridionalis. The period varied more than those of laboratory mice and rats. Generally, the gestation period of rodents is influenced by various factors such as ovulation time after coitus, litter size, population [11], and exercise and body mass of mother [9, 35]. However, the gestation period of the Russian voles ap- peared to be irrespective of litter size, and seemed due to variation of ovulation time after coitus. The females became pregnant continuously after parturition and a maximum of nine consecutive parturitions was observed during 9 months. The parturition interval ranged from 19 to 27 days in the present study. Postpartum mating is quite common in microtine species $[21,26]$, and the parturition interval is reported to vary individually in new world Microtus [11]. The variation in parturition interval is considered to depend on the variation in ovulation time at the postpartum estrous. The parturition interval in the Russian vole is shorter than that of $M$. savii [3] and M. pinetorum [29] as shown in Table 2. The short parturition interval indicates a possibility that lactation may not cause delay in implantation in Microtus [10] and leads to continuous pregnancy, differing from other rodents such as mice, rats and Clethrionomys 
glareolus [1]. Jemiolo [10] stated that longer parturition intervals are probably due to a lack of postpartum mating in the pine vole. The present research revealed great variation in litter size in Russian voles (range: 110). The average litter size was large compared with other captive Microtus, such as M. pinetorum [29] and M. savii [3] as shown in Table 2. The litter size increased with the number of parturition times or maternal age, and the peak was seen at the seventh parturition (Fig. 2). This finding agrees with a previous study on common field voles by Wojciechowska [34]. The small litter size of the first parturition (Fig. 2) seems to be due to insufficient development of reproductive organs in younger females.

The body weight of new born pups at the first and second parturitions was lighter than that in the third and subsequent parturitions (Table 1). The weaning age of Russian voles ranged from 12 to 25 days of age, which is more variable than with 21 days in $M$. pinetorum [17] and 12-14 days in M. montanus [2, 18], but earlier than in the bank vole, the young of which are weaned at 25 days of age [22]. The infant mortality before weaning was $14.4 \%$, and the death of young was mostly seen during the first 5 days of life, as reported for the bank vole [22]. These items also seem to be dependent on maternal reproductive ability. Oswald \& McClure [23] stated that postpartum estrus and ensuing pregnancy concurrent with lactation are widespread among murine rodents. In the Russian vole, the postpartum estrus and ovulation are known to be induced by the presence of a male as in the prairie vole [8]. Moreover, Roberts et al. [27] reported that a prolonged mating period, longer than $12 \mathrm{~h}$, increased the number of embryos. In this study the breeding couples were put together in the same cage continuously, so that the postpartum estrus could be induced by a male partner, and the ensuing continuous pregnancy seems to lead to a short lactation period and early weaning. The average body weights of $18.7 \mathrm{~g}$ at 20 days after birth and $30.3 \mathrm{~g}$ at 6 weeks of age were heavier those reported previously for the same species [35].

The Russian field vole can be used as a model animal for ruminant studies as noted previously, and the breeding colony investigated in the present study is considered to have adapted successfully to the laboratory conditions with controlled lighting and temperature, and the food provided. Therefore, it is suitable for various biological experiments in the laboratory, and furthermore, it was evaluated as an useful laboratory animal by virtue of its excellent reproductive ability: continuous gestation, short parturition interval, relatively large litter size and low infant mortality.

\section{References}

1. Andersson, C.B. and Gustafsson, T.O. 1979. J. Reprod. Fertil. 57: 349-352.

2. Bailey, V. 1924. Jour. Agr. Research 27: 523-535.

3. Caroli, L., Capizzi, D., and Luiselli, L. 2000. Zoolog. Sci. 17: 209-216.

4. Dieterich, R.A. and Preston, D.J. 1977. Lab. Anim. Sci. 27: 494-499.

5. Dieterich, R.A. and Preston, D.J. 1977. Lab. Anim. Sci. 27: 500-506.

6. Goto, N., Hashizume, R., and Sai, I. 1977. J. Mammal. Soc. Jpn. 7: 75-85 (Japanese with English abstract).

7. Goto, N. and Hashizume, R. 1978. J. Mammal. Soc. Jpn. 7: 181-188 (Japanese with English abstract).

8. Hasler, M.J. and Nalbandov, A.V. 1974. Gen. Comp. Endocrinol. 23: 237-238.

9. Hatfield, D.M. 1935. J. Mammal. 16: 261-271.

10. Jemiolo, B. 1983. Acta Theriol. 28: 197-207.

11. Keller, B.L. 1985. pp 725-778. In: Biology of The New World Microtus (Tamarin, R.H. ed.), Am. Soc. Mammal. Spec. Publ. (8).

12. Kenney, A.McM., Evans, R.L., and Dewsbury, D.A. 1977. J. Reprod. Fertil. 49: 365-367.

13. Kirkpatrick, R.L. and Valentine, G.L. 1970. J. Mammal. 51: 779-785.

14. Krebs, C.J., Keller, B.L., and Tamarin, R.H. 1969. Ecology 50: 587-607.

15. Kudo, H. and Oki, Y. 1982. Exp. Anim. 31: 175-183.

16. Kudo, H. and Oki, Y. 1984. Vet. Res. Commun. 8: 77-91.

17. Lochmiller, R.L., Whelan, J.B., and Kirkpatrick, R.L. 1982. J. Mammal. 63: 475-481.

18. McGuire, B. and Novak, M. 1986. J. Mammal. 67: 305311.

19. Morrison, P., Dieterich, R., and Preston, D. 1976. Lab. Anim. Sci. 26: 237-243.

20. Negus, N.C. and Pinter, A.J. 1965. J. Mammal. 46: 434437.

21. Novak, R.M. 1999. Walker's Mammals of the World, 6 th ed., Vol. II, The Johns Hopkins University Press, Baltimore, Maryland.

22. Ödberg, F.O. 1984. Lab. Anim. 18: 33-35.

23. Oswald, C. and McClure, P.A.1987. J. Exp. Zool. 241: 343-357.

24. Paradis, E. 1995. J. Animal Ecology 64: 579-591.

25. Richmond, M. and Conaway, C.H. 1969. Lab. Anim. Care 19: 80-87.

26. Richmond, M. and Stehn, R. 1976. pp 197-214. In: Mammalian Olfaction, Reproductive Processes and Behavior (Doty, R.L. ed.), Academic Press, New York. 
27. Roberts, R.L., Wolf, K.N., Sprangel, M.E., Rall, W.F., and Wildt, D.E. 1999. Biol. Reprod. 60: 756-762.

28. Schadler, M.H. 1978. pp 82-87. In: Proceeding second pine and meadow vole symposium (Byers, R.E. ed.), Beltsville, Maryland.

29. Schadler, M.H. and Butterstein, G.M. 1979. J. Mammal. 60: 841-844.

30. Solomon, N.G., Brant, C.L., Callahan, P.A., and Steinly, Jr.B.A. 2001. Reproduction 122: 297-304.
31. Solomon, N.G. 1991. Lab. Anim. 25: 232-235.

32. Tamarin, R.H. 1977. J. Mammal. 58: 536-548.

33. Wang, Z. and Novak, M.A. 1994. J. Mammal. 75: 18-23.

34. Wojciechowska, B. 1970. Acta Theriol. 15: 81-88.

35. Yoccoz, N.G., Ims, R.A., and Steen, H. 1993. Can. J. Zool. 71: 2518-2527.

36. Yoshinaga, Y., Okayama, T., Ohno, W., and Shiraishi, S. 1997. J. Mammal. 78: 830-838. 